\title{
Transport of the aromatic amino acids into isolated rat liver cells
}

\author{
Properties of uptake by two distinct systems
}

\author{
Mark SALTER, ${ }^{*} \dagger$ Richard G. KNOWLES* and Christopher I. POGSON* \\ Department of Biochemistry, University of Manchester, Oxford Road, Manchester M13 9PL, U.K.
}

\begin{abstract}
1. The transport of the aromatic amino acids into isolated rat liver cells was studied. 2 . There was a rapid and substantial binding of the aromatic amino acids, $\mathrm{L}$-alanine and $\mathrm{L}$-leucine to the plasma membrane. This has important consequences for the determination of rates of transport and intracellular concentrations of the amino acids. 3. Inhibition studies with a variety of substrates of various transport systems gave results consistent with aromatic amino acid transport being catalysed by two systems: a 2-aminobicyclo $(2,2,1)$ heptane2-carboxylic acid (BCH)-insensitive aromatic D- and L-amino acid-specific system, and the L-type system (BCH-sensitive). 4. The $\mathrm{BCH}$-insensitive component of transport was $\mathrm{Na}^{+}$-independent and facilitated non-concentrative transport of the aromatic amino acids; it was unaffected by culture of liver cells for $24 \mathrm{~h}$, by $48 \mathrm{~h}$ starvation, dexamethasone phosphate or glucagon. 5. Kinetic properties of the BCH-inhibitable component were similar to those previously reported for the L2-system in liver cells. The BCH-insensitive component was a comparatively low- $K_{\mathrm{m}}$ low- $V_{\max }$. transport system that we suggest is similar to the T-transport system previously seen only in human red blood cells. The results are discussed with reference to the importance of the T- and L-systems in the control of aromatic L-amino acid degradation in the liver.
\end{abstract}

\section{INTRODUCTION}

The transport of the neutral amino acids into eukaryotic cells is carried out by several distinct systems, with overlapping substrate specificity (Christensen, 1979). Of the transport systems, the $A$, asc, $N$ and Gly systems (Shotwell et al., 1983), require $\mathrm{Na}^{+}$for activity and can concentrate their substrate amino acids against a gradient (Oxender \& Christensen, 1963; Christensen, 1976). Until recently the only $\mathrm{Na}^{+}$independent transport system seen in mammalian cells was the L-system (Inui \& Christensen, 1966; McGivan et al., 1977). System $A$ is responsive to a wide range of hormonal stimuli (Guidotti et al., 1978) and, with system $\mathrm{N}$, is enhanced in starvation (Kilberg, 1982). The other systems, however, appear to be unresponsive to hormones or starvation.

Guidotti et al. (1978) have suggested that the major system responsible for transport of aromatic and branched-chain amino acids into liver cells is the L-system. Weissbach et al. (1982) have shown that in liver cells this system may be subdivided into $L 1$ and $L 2$, both inhibited by the non-metabolizable amino acid analogue 2aminobicyclo(2,2,1)heptane-2-carboxylic acid (BCH). System L2 is quantitatively the most important transport system in freshly prepared rat liver cells (Handlogten et al., 1982); in primary culture, however, transport mediated by system L1 increases, especially at low substrate concentrations (Kilberg et al., 1983). The physiological importance of this change is at present unresolved.

In mammals, the aromatic amino acids L-phenylalanine and L-tryptophan are essential components of the diet, dietary L-tyrosine being supplemented by the hydroxyla- tion of L-phenylalanine in the liver. Their concentrations in the blood are constrained by the rates of protein turnover, dietary intake and metabolism by the liver. The regulation of the blood concentration of these aromatic L-amino acids is of great importance, not least because of their role as precursors of neuroactive amines. It has been widely assumed that the three enzymes responsible for the initial steps in metabolism of the three amino acids are rate-limiting (Badawy \& Evans, 1975; Milstien \& Kaufman, 1975; Tanaka \& Ichihara, 1975; Coufalik \& Monder, 1980; Dickson et al., 1981; Stowell et al., 1983) and that the transporters therefore have a negligible role in the control of these pathways. It is consistent with this view that transport of the aromatic amino acids has been thought to be rapid (Smith \& Pogson, 1980; Dickson et al., 1981; Kilberg et al., 1981; Fisher \& Pogson, 1984). However, preliminary work with L-tryptophan has provided evidence that the transport of this amino acid may be a limiting factor for its hepatic degradation (Salter et al., 1984).

Rosenberg et al. (1980) demonstrated the presence of a $\mathrm{Na}^{+}$-independent transport system specific for aromatic amino acids in human red blood cells, this system co-existing with the lower-affinity L-system. They designated the new system the T-system, and this, with systems $\mathrm{L} 1$ and $\mathrm{L2}$, is the only $\mathrm{Na}^{+}$-independent transport system for neutral amino acids seen in eukaryotic cells. Previous work in this laboratory has shown that the maximally effective concentration of L-leucine, a substrate of the L1 and L2 systems (Handlogten et al., 1982), only partially inhibited the transport of $50 \mu \mathrm{M}$-L-tryptophan into isolated rat liver cells (Salter et al., 1985a). The purpose of this work was to characterize the remaining component of transport

\footnotetext{
Abbreviation used: BCH, 2-aminobicyclo(2,2,1)heptane-2-carboxylic acid.

* Present address: Biochemistry Department, Wellcome Research Laboratories, Langley Court, Beckenham, Kent BR3 3BS, U.K.

$\dagger$ To whom correspondence and reprint requests should be addressed.
} 
and to elucidate its role in the transport of $\mathrm{L}$-phenylalanine and L-tyrosine. In the present paper we describe the presence and properties of a $\mathrm{Na}^{+}$-independent non-BCHinhibitable component of transport, specific for the aromatic amino acids. We designate this the T-system, by analogy with the T-system described for human red blood cells (Rosenberg et al., 1980).

A preliminary description of part of this work has appeared (Salter et al., 1985b).

\section{MATERIALS AND METHODS}

\section{Animals}

Male Sprague-Dawley rats (180-220 g) were fed on a standard laboratory diet (CRM diet; Labsure, Poole, Dorset, U.K.). Dexamethasone phosphate was administered intraperitoneally, $5 \mathrm{~h}$ before liver cell preparation ( $3 \mathrm{mg} /$ animal, in $0.9 \% \mathrm{NaCl}$ ).

\section{Chemicals}

All radiolabelled compounds were from Amersham International, Amersham, Bucks., U.K. D- and L-amino acids and model substrates were from Sigma. The 'silicone oil' used was a $2: 1(\mathrm{v} / \mathrm{v})$ mixture of Dow Corning 550 and dinonyl phthalate, and was supplied by BDH Chemicals, Poole, Dorset, U.K. The sources of other reagents were as given previously (Smith \& Pogson, 1980; Smith et al., 1980).

\section{Purification of radiolabelled compounds}

Radiolabelled L-[G- $\left.{ }^{3} \mathrm{H}\right]-$ and $\mathrm{D}-$ and $\mathrm{L}-[$ benzene ringU-14C]tryptophan were purified by affinity chromatography (Stewart \& Doherty, 1973). Radiolabelled phenylalanine and tyrosine were purified as described by Salter et al. (1984).

\section{Preparation and incubation of cells}

The procedures were as described previously (Salter et al., 1984), with the following amendments: (1) perfusions were started at 12:00-13:00 $\mathrm{h}$ each day; (2) perfusion medium contained $20 \mathrm{~mm}-\mathrm{D}$-glucose; (3) cells were washed without albumin in the medium described below; (4) the incubation medium consisted of buffer (Krebs \& Henseleit, 1932) containing $2.5 \mathrm{~mm}-\mathrm{Ca}^{2+}$ and supplemented with $5 \mathrm{~mm}$-D-glucose, $5 \mathrm{~mm}$-L-glutamine (unless otherwise stated), $4.5 \mathrm{~mm}$-L-lactate, $0.5 \mathrm{mM}$ pyruvate (Salter et al., 1984) and transport inhibitors where relevant. The final cell concentration was approx. $3 \mathrm{mg} / \mathrm{ml}$ for flux measurements and $6 \mathrm{mg} / \mathrm{ml}$ for measurement of amino acid uptake. Fluxes through the pathways of aromatic amino acid metabolism were measured as described previously (Salter et al., 1984, and references therein).

In a few experiments, $2 \mathrm{ml}$ (approx. $2 \mathrm{mg}$ dry wt. of cells) of cell suspension was plated on to collagen-coated dishes in Waymouth's medium MB 752/1 (Gibco, Uxbridge, Middx., U.K.), containing $0.2 \%$ (w/v) bovine serum albumin and $5 \mu \mathrm{g}$ of sodium oleate $/ \mathrm{ml}$; dishes were kept for $24 \mathrm{~h}$ at $37^{\circ} \mathrm{C}$. The medium was replaced $1 \mathrm{~h}$ before transport assays by amino-acid-free buffer in which $25 \mathrm{~mm}$-Hepes replaced the bicarbonate (Krebs-Hepes).

\section{Amino acid uptake}

A sample (1.5 ml; $9 \mathrm{mg}$ dry wt.) of isolated rat liver cells in suspension was preincubated for $25 \mathrm{~min}$ at $37^{\circ} \mathrm{C}$ under an atmosphere of $\mathrm{O}_{2} / \mathrm{CO}_{2}(19: 1)$ and shaken at 100 oscillations/min before addition of radiolabelled amino acid substrate. Cell suspension $(1 \mathrm{ml})$ was layered on to $250 \mu \mathrm{l}$ of the 'silicone oil' and centrifuged $(15 \mathrm{~s}, 12000 \mathrm{~g})$ such that the cells passed through the 'silicone oil' into $100 \mu 1$ of $6 \%(\mathrm{v} / \mathrm{v}) \mathrm{HClO}_{4}$. Rates of transport of amino acids other than L-phenylalanine were determined from the difference in cell-associated radioactivity between 5 and $15 \mathrm{~s}$ ( 5 and $12.5 \mathrm{~s}$ for L-phenylalanine); transport remained linear over $30 \mathrm{~s}$ ( $20 \mathrm{~s}$ for phenylalanine). Calculations of rates of pre-steady-state metabolism, based on the known kinetic properties of the enzymes responsible for the initial degradation of the aromatic amino acids (M. Salter \& C. I. Pogson, unpublished work; Carr \& Pogson, 1981), suggest that less than $8 \%$ of the intracellular amino acids would be metabolized during the transport assays over the range of concentrations of amino acids used; of the products of metabolism, only a small proportion would be predicted to leave the cell during the $12.5 \mathrm{~s}$ or $15 \mathrm{~s}$ of the transport assay. The volumes of intra- and extra-cellular spaces carried down through the 'silicone oil' were determined simultaneously by measuring the ${ }^{3} \mathrm{H}_{2} \mathrm{O}$ - and $\left[\mathrm{U}_{-14}{ }^{14} \mathrm{C}\right]$ sucrose-permeated spaces. The intra- and extra-cellular spaces were found to be reproducible between different liver cell preparations: $2.05 \pm 0.10 \mu \mathrm{l} / \mathrm{mg}$ dry wt. and $1.51 \pm 0.07 \mu \mathrm{l} / \mathrm{mg}$ dry wt. respectively (both \pm S.E.M.; $n=3$ ); these values are in agreement with those obtained previously (Fisher \& Pogson, 1984), and were not significantly changed by different incubation conditions.

Liver cell cultures were preincubated for $1 \mathrm{~h}$ in Krebs-Hepes medium before addition of radiolabelled substrate. After $5 \mathrm{~s}$, or at the end of the incubation (12.5 or $15 \mathrm{~s}$; see above) the medium was rapidly removed by aspiration and replaced by ice-cold Krebs-Hepes, which was then rapidly replaced by $6 \% \mathrm{HClO}_{4}$. Samples of this and of the original medium were counted for radioactivity.

\section{Cell viability}

Cell viability was assessed by the measurement of cellular ATP (Stanley \& Williams, 1969).

\section{RESULTS AND DISCUSSION}

\section{Rapid binding of amino acids to the cell membrane}

Fig. 1 shows time courses of the association of radioactive aromatic $L$-amino acids and $L$-leucine with liver cells. The increase in radioactivity was linear from $5 \mathrm{~s}$ onwards for all the amino acids used, after which the rate decreased to zero or to a low constant value dictated by the rate of further metabolism and release of products. After allowance for contamination by extracellular fluid, a substantial proportion of cell-associated radioactivity was found to be present at $5 \mathrm{~s}$. Because $5 \mathrm{~s}$ was the earliest time point measurable with the techniques used in this study, further resolution of this rapid association was not achieved. McGivan et al. (1977) have previously reported an apparent rapid association of L-leucine with liver cells, and they attribute this phenomenon to a presumed 'dead time', of the centrifuged separation of cells from medium through silicone oil, of $6 \mathrm{~s}$. In order to determine the true 


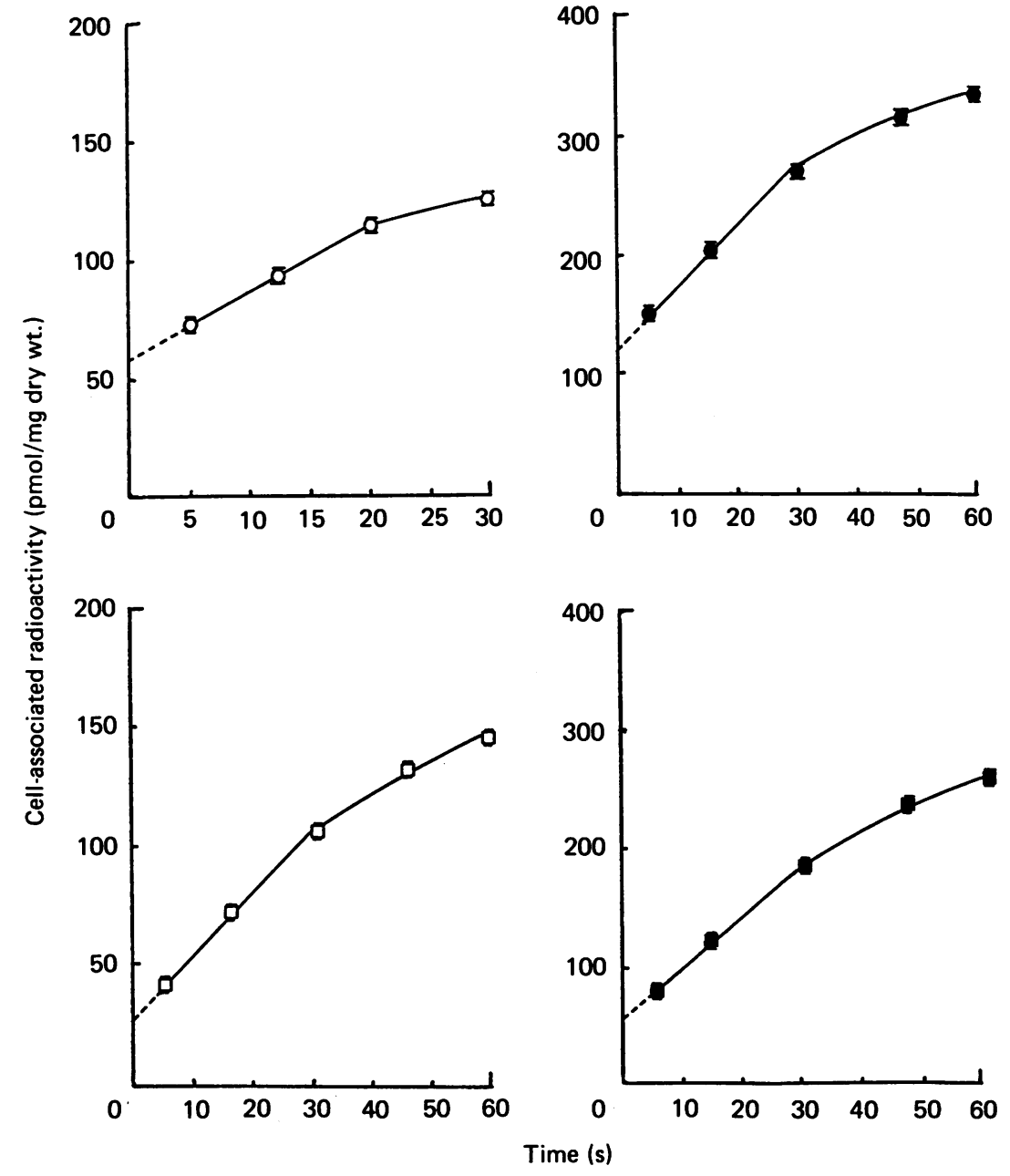

Fig. 1. Association of radioactivity with liver cells incubated with aromatic amino acids and leucine

Methods were as described in the text: $\square, 50 \mu \mathrm{M}$-L-tryptophan; $\mathrm{O}, 50 \mu \mathrm{M}$-L-phenylalanine; $\square, 100 \mu \mathrm{M}$-L-tyrosine; $100 \mu \mathrm{M}$-L-leucine. Results are means \pm S.E.M. from three separate liver cell preparations.

'dead time' of this technique in our hands, we have measured the uptake of 2-deoxy-D-[1-3 H]glucose into liver cells over $60 \mathrm{~s}$ (Fig. 2); inhibitor-stop techniques have demonstrated that this process is linear between 0 and $2 \mathrm{~min}$ (K. R. F. Elliott, personal communication). The 'dead time' determined by this method was less than $0.5 \mathrm{~s}$; this is far too small to explain the amounts of amino acids associated with isolated liver cells at $5 \mathrm{~s}$. Substantial inhibition of the linear rate of uptake of radiolabelled amino acids, either by large concentrations of competing amino acids or by performance of incubations at $2^{\circ} \mathrm{C}$, did not decrease the rapid association of radioactivity with the liver cells by more than $20 \%$ (results not shown). This again suggests that the rapid association is not an artifact caused by the 'dead time' of the technique; the lack of substantial inhibition of this rapid association by performance of the incubations at $2{ }^{\circ} \mathrm{C}$ also suggests that rapid carrier-mediated uptake is not responsible. It therefore seems likely that the rapid association of aromatic L-amino acids and L-leucine with isolated liver cells consists of binding to the plasma membrane. This binding demonstrated a linear concentration-dependence up to $2 \mathrm{~mm}$, and was not stereospecific, since D-tryptophan was also bound (results not shown). The amounts of different amino acids which bound to isolated liver cells at a given concentration of the amino acid varied considerably: L-phenylalanine $=$ L-leucine $>$ L-tryptophan $=$ L-alanine $\gg$ L-glutamine .

Allowance for the non-specific binding component, which is irrelevant to the transport of the amino acid itself, is important both for the determination of initial rates of transport and for the calculation of intracellular concentrations of amino acids at steady-state. Work from this laboratory and others (Smith \& Pogson, 1980; Dickson et al., 1981; Kilberg et al., 1981; Fisher \& Pogson, 1984) has suggested that transport of aromatic amino acids is rapid relative to subsequent metabolism and that equilibrium between external and internal pools of the amino acids is rapidly achieved. Rates of transport calculated from the linear transport phase, however, are much closer to the rates of metabolism. In addition, when non-specific binding is taken into account in determining the cellular internal concentrations of these amino acids, the internal and external pools are, at steady state, not at equilibrium with each other. This in turn suggests that transport of the aromatic amino acids may be an important factor in determining the rate of further metabolism. 


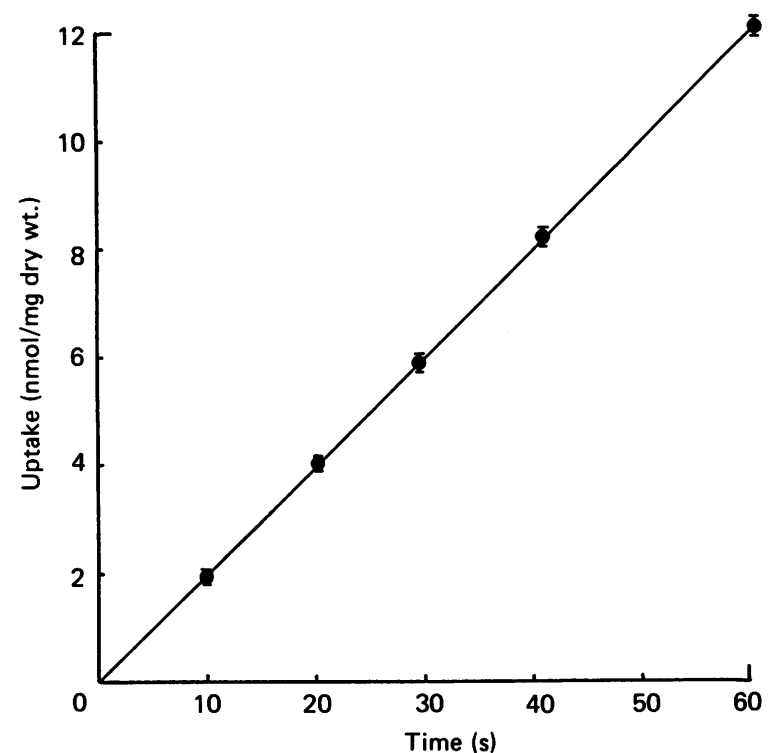

Fig. 2. Time course of the uptake of 2 -deoxy-D-[1-3 $\mathbf{H}]$ glucose into isolated rat liver cells

Rat liver cells were prepared and incubated as described in the Materials and methods section. The concentration of 2-deoxy-D-glucose was $1 \mathrm{mM}$. Each point represents the mean \pm S.D. of three samples from one liver cell preparation.

\section{Heterogeneity of aromatic amino acid transport}

The possibility that the A-, N-, asc-, Gly-or $\mathrm{Ly}^{+}$-systems are involved in the transport of the aromatic amino acids into isolated liver cells was investigated with 2methylaminoisobutyric acid, L-glutamine, L-alanine, Lserine, glycine and L-arginine; these are known to be substrates for these systems (Guidotti et al., 1978; Christensen, 1979; Shotwell et al., 1983). At $20 \mathrm{~mm}$, these amino acids had no significant effect on the transport of L-tryptophan, L-tyrosine or L-phenylalanine (results not shown).

In contrast, amino acids which have been reported to be substrates for L-systems in various tissues, including liver cells (Guidotti et al., 1978; Weissbach et al., 1982), L-leucine, L-isoleucine, L-histidine, L-methionine and L-valine, all significantly inhibited transport of the aromatic amino acids into isolated liver cells (Table 1). BCH has been shown to be a specific L-system model substrate in Ehrlich ascites cells (Christensen, 1979), and has also been shown to be a substrate for systems $\mathrm{Ll}$ and L2 in isolated liver cells (Weissbach et al., 1982). Table 1 and Fig. 3 show that $\mathrm{BCH}$ also inhibited transport of the aromatic amino acids into liver cells. The $I_{50}$ (the concentration which gives half-maximal inhibition) for BCH was similar to the reported $K_{\mathrm{m}}$ value for the L-system, L2, which predominates in freshly isolated rat liver cells (Handlogten et al., 1982).

Table 1 shows that the effects of $\mathrm{BCH}$ and other L-system substrates on aromatic amino acid transport were not additive; the maximum inhibition was approx. $50 \%$. Incubation of liver cells with a range of concentrations of L-phenylalanine, however, showed that this amino acid could almost totally inhibit the transport of $50 \mu \mathrm{M}$-L-tryptophan (Fig. 3). Similarly L-tryptophan inhibited the transport of $50 \mu \mathrm{M}-\mathrm{L}$-phenylalanine. LTyrosine when added (at $3.5 \mathrm{~mm}$ ) to a maximally effective concentration of $\mathrm{BCH}$ increased the inhibition of $50 \mu \mathrm{M}$-L-phenylalanine and $50 \mu \mathrm{M}-\mathrm{L}$-tryptophan transport (Table 1); the limited solubility of L-tyrosine precluded the use of higher concentrations. These results show that transport of aromatic L-amino acids into liver cells is mediated not only by a BCH-sensitive system but also by an as yet uncharacterized component of transport specific for the aromatic amino acids.

Table 1. Effect of some $L$-system substrates on aromatic L-amino acid transport into isolated rat liver cells

Procedures were as described in the Materials and methods section. Concentrations of aromatic L-amino acid substrates were $50 \mu \mathrm{M}$ (L-tryptophan and L-phenylalanine) and $100 \mu \mathrm{M}$ (L-tyrosine). Control values of transport were 10.15 \pm 0.65 (L-tryptophan), $10.40 \pm 0.95$ ( $\mathrm{L}$-phenylalanine) and $16.20 \pm 1.60$ ( $\mathrm{L}$-tyrosine) $\mathrm{nmol} / \mathrm{h}$ per $\mathrm{mg}$ dry wt. Results are means \pm S.E.M. from three separate liver cell preparations.

\begin{tabular}{|c|c|c|c|c|}
\hline \multirow{2}{*}{$\begin{array}{l}\text { Amino acid } \\
(20 \mathrm{~mm})\end{array}$} & \multirow{2}{*}{$\begin{array}{c}\text { BCH } \\
(20 \mathrm{~mm})\end{array}$} & \multicolumn{3}{|c|}{ Rates of transport ( $\%$ of control) } \\
\hline & & L-Tryptophan & L-Phenylalanine & L-Tyrosine \\
\hline- & - & $100 \pm 6$ & $100 \pm 9$ & $100 \pm 9$ \\
\hline- & + & $50 \pm 4$ & $43 \pm 6$ & $55 \pm 5$ \\
\hline L-Leucine & - & $52 \pm 3$ & $41 \pm 4$ & $60 \pm 3$ \\
\hline L-Leucine & + & $45 \pm 2$ & $46 \pm 3$ & $58 \pm 3$ \\
\hline L-Isoleucine & - & $52 \pm 3$ & $50 \pm 3$ & $56 \pm 4$ \\
\hline L-Isoleucine & + & $50 \pm 3$ & $50 \pm 3$ & $59 \pm 3$ \\
\hline L-Histidine & - & $55 \pm 5$ & $50 \pm 4$ & $53 \pm 5$ \\
\hline L-Histidine & + & $51 \pm 3$ & $52 \pm 4$ & $54 \pm 4$ \\
\hline L-Methionine & - & $62 \pm 3$ & $48 \pm 3$ & $60 \pm 3$ \\
\hline L-Methionine & + & $58 \pm 2$ & $49 \pm 5$ & $58 \pm 3$ \\
\hline L-Valine & - & $55 \pm 1$ & $47 \pm 3$ & $53 \pm 2$ \\
\hline L-Valine & + & $54 \pm 2$ & $51 \pm 4$ & $51 \pm 4$ \\
\hline L-Tyrosine (3.5 mM) & - & $45 \pm 3$ & $51 \pm 2$ & - \\
\hline L-Tyrosine (3.5 mM) & + & $25 \pm 2$ & $27 \pm 1$ & - \\
\hline
\end{tabular}




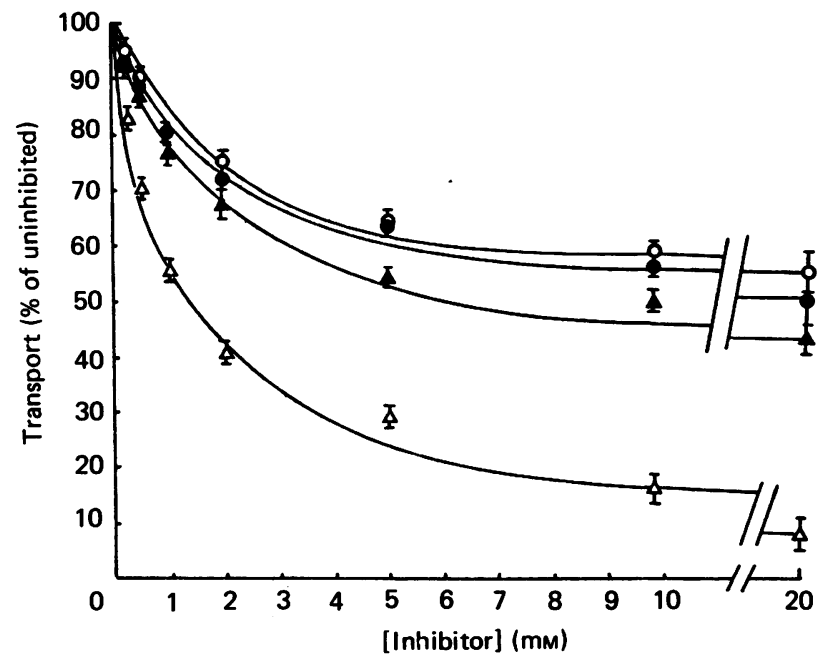

Fig. 3. Effect of BCH and L-phenylalanine on transport of aromatic $L$-amino acids into isolated rat liver cells

Procedures were as described in the Materials and methods section. $O$, Effect of $\mathrm{BCH}$ on L-tyrosine transport; $O$, effect of $\mathbf{B C H}$ on L-tryptophan transport; $\triangle$, effect of $\mathbf{B C H}$ on L-phenylalanine transport; $\triangle$, effect of L-phenylalanine on L-tryptophan transport. Concentrations of aromatic L-amino acid substrates were $50 \mu \mathrm{M}$ (L-tryptophan and $\mathrm{L}$-phenylalanine) and $100 \mu \mathrm{M}$ (L-tyrosine). Control values of transport were $10.10 \pm 0.50$ (L-tryptophan), $10.25 \pm 1.00$ (L-phenylalanine) and $16.45 \pm 0.90$ (L-tyrosine) $\mathrm{nmol} / \mathrm{h}$ per $\mathrm{mg}$ dry wt. Each point represents the mean \pm S.E.M. from three separate liver cell preparations. All transport rates were corrected for radioactivity associated with the cells at $5 \mathrm{~s}$ (see the text).

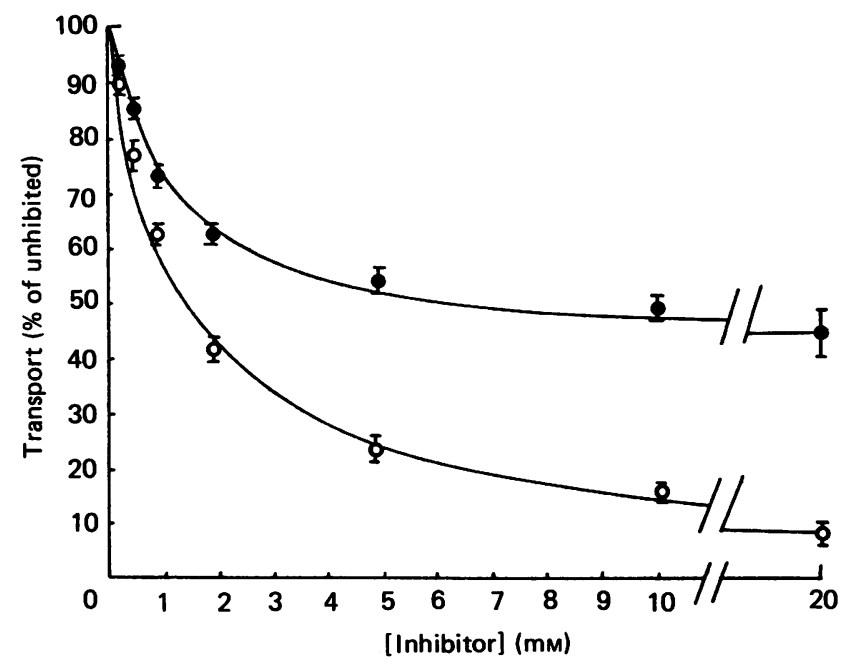

Fig. 4. Effect of D-phenylalanine and BCH on transport of L-tryptophan into isolated rat liver cells

Procedures were as described in the Materials and methods section. E, Effect of D-phenylalanine on L-tryptophan transport; $O$, effect of $D$-phenylalanine plus $B C H$ on L-tryptophan transport. Concentration of L-tryptophan was $50 \mathrm{~mm}$. Control value of L-tryptophan transport was $10.35 \pm 0.75 \mathrm{nmol} / \mathrm{h}$ per $\mathrm{mg}$ dry wt. Each point represents the mean \pm S.E.M. from three separate liver cell preparations. All transport rates were corrected for radioactivity associated with the cells at $5 \mathrm{~s}$ (see the text).

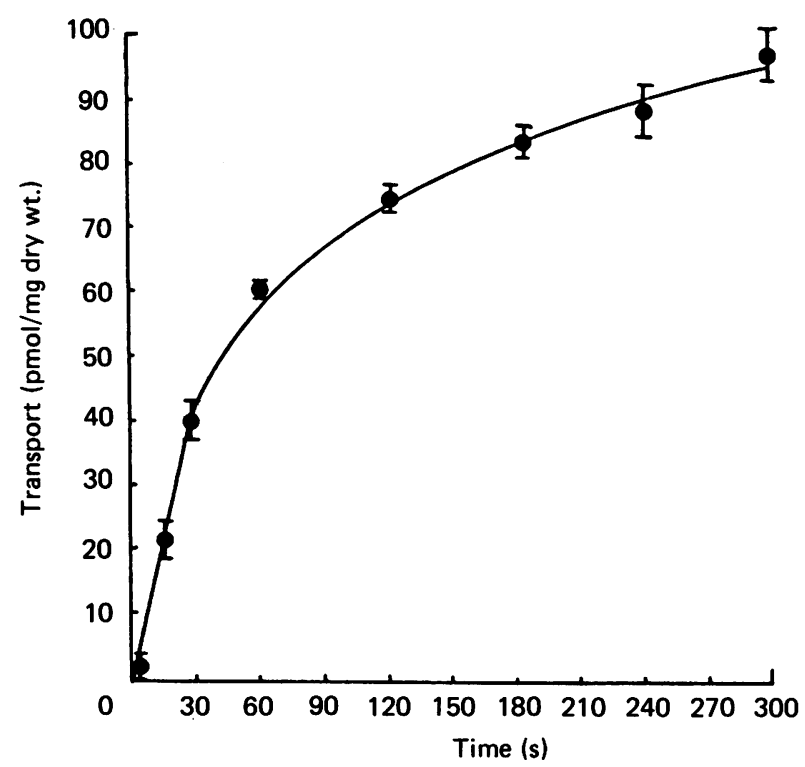

Fig. 5. Time course of the transport of D-tryptophan into isolated rat liver cells

Rat liver cells were prepared and incubated as described in the Materials and methods section. The concentration of D-tryptophan was $50 \mu \mathrm{M}$. Each point represents the mean \pm S.D. of three samples from one liver cell preparation. The amount of D-tryptophan rapidly bound to the liver cells ( $29 \mathrm{pmol} / \mathrm{mg}$ dry wt.) has been subtracted; the data plotted therefore represent only transport into the liver cells.

\section{Properties of the BCH-insensitive component of transport}

Rosenberg et al. (1980) presented evidence for an aromatic D- and L- amino-acid-specific transport system (designated the T-system) in human red blood cells. Incubation of liver cells with D-phenylalanine inhibited the transport of $50 \mu \mathrm{M}$-L-tryptophan (Fig. 4) and of $100 \mu \mathrm{M}$-L-tyrosine to a maximum of approx. $50 \%$. D-Tryptophan also inhibited the transport of $50 \mu \mathrm{M}-\mathrm{L}-$ phenylalanine and $100 \mu \mathrm{M}$-L-tyrosine to a similar extent (results not shown). Experiments performed with a range of concentrations of BCH and D-phenylalanine demonstrated that maximally effective concentrations of both added together almost totally inhibited the transport of $50 \mu \mathrm{M}$-L-tryptophan (Fig. 4). When similar experiments were carried out with D-tryptopan and $\mathrm{BCH}$, a similar and almost total inhibition of the transport of $50 \mu \mathrm{M}$ $\mathrm{L}$-phenylalanine and $100 \mu \mathrm{M}$-L-tyrosine was seen (results not shown).

D-Tryptophan was a substrate for transport by the BCH-insensitive component; Fig. 5 shows the time course of transport of the D-amino acid into liver cells. A maximally effective concentration of $\mathrm{BCH}$ inhibited the transport of $\mathrm{D}-\left[{ }^{14} \mathrm{C}\right]$ tryptophan by less than $10 \%$; D-phenylalanine and unlabelled D-tryptophan, however, almost completely inhibited its transport.

The BCH-insensitive component was shown to be $\mathrm{Na}^{+}$-independent; replacement of $\mathrm{Na}^{+}$with choline ${ }^{+}$did not significantly alter the rates of transport of the amino acids or the extent of inhibition of transport by $\mathrm{BCH}$ (results not shown). Both components of transport facilitated non-concentrative transport; when L-tyrosine metabolism was inhibited by amino-oxyacetate (Dickson 

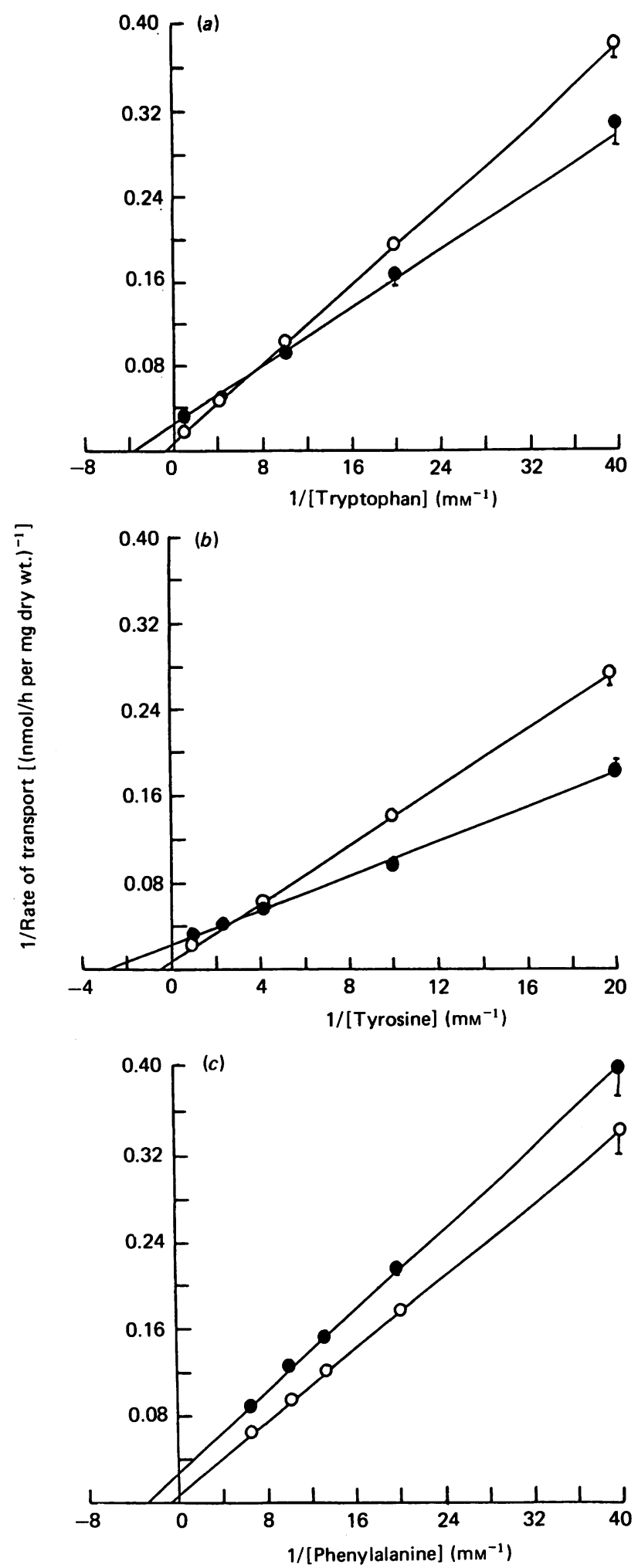

Fig. 6. Lineweaver-Burk plots of the transport of L-tryptophan (a), L-tyrosine (b) and L-phenylalanine (c) into rat liver cells

Procedures were as described in the Materials and methods section. Each point represents the mean \pm S.D. of three samples from one liver cell preparation., $\mathrm{BCH}$-insensitive transport; $\mathrm{O}, \mathrm{BCH}$-sensitive transport. The concentration of $\mathrm{BCH}$ was $30 \mathrm{~mm}$. The transport rates used to derive these plots were all corrected for radioactivity associated with the cells at $5 \mathrm{~s}$ (see the text). et al., 1981), the internal and external L-tyrosine pools equilibrated, in both the presence and the absence of $\mathrm{BCH}$. These properties of this novel transport system in liver are remarkably similar to those reported for the T-system in human red blood cells (Rosenberg et al., 1980).

$\mathrm{BCH}$-insensitive transport of the aromatic amino acids proved insensitive to pre-treatment of the rats (by either starvation for $48 \mathrm{~h}$ or injection with dexamethasone phosphate), to incubation with glucagon, or to culture of the cells for $24 \mathrm{~h}$.

\section{Kinetic properties of the components of aromatic amino acid transport}

The kinetic properties of both the components of transport were determined from measurements of the rates of aromatic L-amino acid transport, at different substrate concentrations, in the presence and absence of $\mathrm{BCH}$; the portion of transport inhibited by $\mathrm{BCH}$ was ascribed to L-type system(s). The time courses of transport of the aromatic L-amino acids were linear between 5 and $30 \mathrm{~s}$ ( 5 and $20 \mathrm{~s}$ for phenylalanine) at all the substrate concentrations used.

Fig. 6 shows Lineweaver-Burk plots of the transport of L-tryptophan, L-tyrosine and L-phenylalanine by the $\mathrm{BCH}$-sensitive and -insensitive components. These data provide no evidence for a non-saturable component of amino acid transport such as has been suggested to occur in isolated liver cells (Le Cam \& Freychet, 1977; McGivan et al., 1977). Both the BCH-sensitive and BCH-insensitive components exhibited Michaelis-Menten kinetics with the kinetic constants shown (Table 2). The $K_{\mathrm{m}}$ and $V_{\max }$. values of the $\mathrm{BCH}$-sensitive component of transport were similar to those reported previously for the predominant L2-system in liver cells (Kilberg et al., 1983; Table 2). Although there was a large difference in total capacity $\left(V_{\max }\right)$ between them, these two systems would have, at physiological concentrations of the aromatic L-amino acids, an approximately equal quantitative role in the transport of their substrates.

\section{GENERAL DISCUSSION}

Until recently, only two $\mathrm{Na}^{+}$-independent transport systems for the neutral amino acids had been seen in liver cells, the L1- and L2-systems (Weissbach et al., 1982). These transport systems were thought to be responsible for all transport of the aromatic amino acids into the liver. Rosenberg et al. (1980) have described a $\mathrm{Na}^{+}$-independent aromatic amino-acid-specific transport system in human red blood cells. This system was shown to have a low $K_{\mathrm{m}}$ and $V_{\max }$. relative to the L-type system coexisting in the red-blood-cell membrane, and a pattern similar to this, in respect of the $\mathrm{BCH}$-sensitive (L-type) and the $\mathrm{BCH}$ insensitive components of transport, was observed in the present study. The great similarity between the properties of the $\mathrm{BCH}$-insensitive component described here to those of the T-system in human red blood cells prompts us to suggest that this novel transport system in the liver should also be assigned to the T-system. The presence of this system in tissues from two such divergent sources indicates that this system may have a wide tissue and species distribution.

The liver is quantitatively the most important site of aromatic L-amino acid metabolism in the body (Salter et al., 1984). The regulation of the concentration of the 
Table 2. Kinetic constants for aromatic L-amino acid transport into isolated rat liver cells

Rat liver cells were prepared and incubated as described in the Materials and methods section. Values shown were obtained with a single liver cell preparation ( $L$-phenylalanine and L-tyrosine) or are means \pm S.E.M. from three liver cell preparations (L-tryptophan).

\begin{tabular}{|c|c|c|c|c|}
\hline \multirow[b]{2}{*}{ Amino acid } & \multicolumn{2}{|c|}{ BCH-sensitive component } & \multicolumn{2}{|c|}{$\mathrm{BCH}$-insensitive component } \\
\hline & $K_{\mathrm{m}}(\mathrm{mM})$ & $\begin{array}{c}V_{\max } \\
\text { (nmol/h per mg dry wt.) }\end{array}$ & $K_{\mathrm{m}}(\mathrm{mM})$ & $\begin{array}{c}V_{\max .} \\
\text { (nmol/h per mg dry wt.) }\end{array}$ \\
\hline $\begin{array}{l}\text { L-Tryptophan } \\
\text { L-Tyrosine } \\
\text { L-Phenylalanine }\end{array}$ & $\begin{array}{l}1.65 \pm 0.15 \\
1.95 \\
1.60\end{array}$ & $\begin{array}{l}170 \pm 19 \\
146 \\
195\end{array}$ & $\begin{array}{l}0.25 \pm 0.04 \\
0.29 \\
0.36\end{array}$ & $\begin{array}{l}34.5 \pm 6.00 \\
39.0 \\
37.5\end{array}$ \\
\hline
\end{tabular}

aromatic L-amino acids in blood by this metabolism is thought to play a key role in regulating the synthesis of the related biogenic amines in the brain (Peters \& Buhr, 1984). It has been thought until now that tryptophan 2,3-dioxygenase(EC 1.13.11.11), phenylalanine hydroxylase (EC 1.14.16.1) and tyrosine aminotransferase (EC 2.6.1.5) are the rate-limiting enzymes of aromatic amino acid catabolism. Comparison of the rates of transport determined here with the rates of metabolism (Salter et al., 1984) shows, however, that transport processes have a regulatory role in these pathways. Fluctuations in the blood concentrations of the $\mathrm{L}$-amino acids transported by L-type systems, and particularly those transported by both $\mathrm{T}$ - and L-type systems (the aromatic L-amino acids), arising from changes in either dietary content or metabolic turnover, will influence the rates of transport and thus disposal of the aromatic L-amino acids. For example, a mixture of all the L-amino acids (except L-tryptophan) at their physiological portal-vein concentrations (A. J. Dickson, personal communication) inhibited the transport of L-tryptophan $(10 \mu \mathrm{M})$ by $29 \%$ and $33 \%$ in two separate liver cell preparations.

Competition for transport of the aromatic L-amino acids across the blood-brain barrier (Pardridge, 1977; Bloxam et al., 1980) or the synaptosomal plasma membrane (Aragon et al., 1981; Knowles \& Pogson, 1984a) may decrease the synthesis of neuroactive amines (Fernstrom \& Wurtman, 1972; Knowles \& Pogson, 1984b). The present results suggest that competition for transport of the aromatic $\mathrm{L}$-amino acids across the liver plasma membranes may indirectly increase such synthesis by causing a decrease in catabolism of these amino acids and thus increasing their concentrations in the blood.

We gratefully acknowledge financial support from the Medical Research Council.

\section{REFERENCES}

Aragon, M. C., Gimenez, C., Mayor, F., Jr., Maruizon, J. G. \& Valdivieso, F. (1981) Biochim. Biophys. Acta 646, 465470

Badawy, A. A.-B. \& Evans, M. (1975) Biochem. J. 148, 425-432

Bloxam, D. L., Tricklebank, M. D., Patel, A. J. \& Curzon, G. (1980) J. Neurochem. 34, 43-49

Carr, F. P. A. \& Pogson, C. I. (1981) Biochem. J. 198, 655660

Vol. 233
Christensen, H. N. (1976) in Transport Phenomena in the Nervous System (Levi, G., Battistin, L. \& Lajtha, A., eds.), pp. 3-12, Plenum, New York

Christensen, H. N. (1979) Adv. Enzymol. 49, 41-101

Coufalik, A. H. \& Monder, C. (1980) Arch. Biochem. Biophys. 199, 67-73

Dickson, A. J., Marston, F. A. O. \& Pogson, C. I. (1981) FEBS Lett. 127, 28-32

Fernstrom, J. D. \& Wurtman, R. J. (1972) Metab. Clin. Exp. 21, 337-342

Fisher, M. J. \& Pogson, C. I. (1984) Biochem. J. 219, 79-85

Guidotti, G. G., Borghetti, A. F. \& Gazzola, G. C. (1978) Biochim. Biophys. Acta 515, 329-366

Handlogten, M. E., Weissbach, L. \& Kilberg, M. S. (1982) Biochem. Biophys. Res. Commun. 104, 307-313

Inui, Y. \& Christensen, H. N. (1966) J. Gen. Physiol. 50, 203-224

Kilberg, M. S. (1982) J. Membr. Biol. 69, 1-12

Kilberg, M. S., Handlogten, M. E. \& Christensen, H. N. (1981) J. Biol. Chem. 256, 3304-3312

Kilberg, M. S., Weissbach, L. \& Barber, E. F. (1983) in Isolation, Characterization and Use of Hepatocytes (Harris, R. A. \& Cornell, N. W., eds.). pp. 227-232, Elsevier Science Publishing Co., New York

Knowles, R. G. \& Pogson, C. I. (1984a) J. Neurochem. 42, 663-664

Knowles, R. G. \& Pogson, C. I. (1984b) J. Neurochem. 42, 677-684

Krebs, H. A. \& Henseleit, K. (1932) Hoppe-Seyler's Z. Physiol. Chem. 210, 33-66

Le Cam, A. \& Freychet, P. (1977) J. Biol. Chem. 252, 148-156

McGivan, J. D., Bradford, N. M. \& Mendez-Mourao, J. (1977) FEBS Lett. 80, 380-384

Milstien, S. \& Kaufman, S. (1975) J. Biol. Chem. 250, 4782-4785

Oxender, D. L. \& Christensen, H. N. (1963) J. Biol. Chem. 238, 3686-3699

Pardridge, W. M. (1977) J. Neurochem. 28, 103-108

Peters, R. I. \& Buhr, B. R. (1984) Neurochem. Int. 6, 685-691

Rosenberg, R., Young, J. D. \& Ellory, J. C. (1980) Biochim. Biophys. Acta 598, 375-384

Salter, M., Stanley, J. C., Fisher, M. J. \& Pogson, C. I. (1984) Biochem. J. 221, 431-438

Salter, M., Bender, D. A. \& Pogson, C. I. (1985a) Biochem. J. 225, 277-281

Salter, M., Knowles, R. G. \& Pogson, C. I. (1985b) Biochem. Soc. Trans. 13, 693-694

Shotwell, M. A., Kilberg, M. S. \& Oxender, D. L. (1983) Biochim. Biophys. Acta 737, 267-284

Smith, S. A. \& Pogson, C. I. (1980) Biochem. J. 186, 977-986

Smith, S. A., Carr, F. P. A. \& Pogson, C. I. (1980) Biochem. J. 192, 673-686

Stanley, P. E. \& Williams, S. G. (1969) Anal. Biochem. 29, 381-392 
Stewart, K. K. \& Doherty, R. F. (1973) Proc. Natl. Acad. Sci. U.S.A. 70, 2850-2852

Stowell, L., Stowell, A. \& Morland, J. (1983) Alcohol Alcohol. 18, 119-127

Received 25 March 1985/22 August 1985; accepted 18 September 1985
Tanaka, K. \& Ichihara, A. (1975) Biochim. Biophys. Acta 339, 302-312

Weissbach, L., Handlogten, M. E., Christensen, H. N. \& Kilberg, M. S. (1982) J. Biol. Chem. 257, 12006-12011 